\title{
PREDICTING NEUROLOGICAL COMPLICATIONS FOLLOWING ACUTE BACTERIAL MENINGITIS IN CHILDREN VERSUS ADULTS
}

\author{
By \\ OMAIMA ELHENAWY ${ }^{1}$, NADIA A. ABDELKADER ${ }^{2}$, REEM ELMESSIERY ${ }^{1}$, \\ M.FARID ${ }^{3}$, DALIA M. GHORABA ${ }^{2^{\star}}$, and MOAZ HEIKEL ${ }^{4}$ \\ Department of Internal Medicine, Faculty of Medicine, Cairo University ${ }^{1}$, Department \\ of Tropical Medicine, Faculty of Medicine, Ain Shams University ${ }^{2}$, Department of \\ Internal Medicine, Faculty of Medicine, Beni-Suef University ${ }^{3}$ and Shebin El-Kom \\ Fever Hospital, Ministery of Health and Population ${ }^{4}$, Egypt \\ (Correspondence:Dr.daliaghoraba@yahoo.com, Mobile:01022424319)
}

\section{Abstract}

This study determined the predictors for neurological complications of bacterial meningitis in children versus adult patients. This is a prospective study that enrolled 155 Egyptian patients with suspected acute bacterial meningitis ( 80 children less than 16 years and 75 adults more than 16 years), treated for bacterial meningitis in Shebin El-kom Fever Hospital. Nine relevant predictors were chosen to analyze their association with the incidence of neurological complications. P-value $<0.05$ was considered statistically significant .Of 80 children, who were treated for bact-erial meningitis, 8 children developed neurological complications $(10 \%)$ without children death $(0 \%)$. The most important predictors for neurological complications in pediatric patients with bacterial meningitis were: age < 1 year (6.3\%), seizures on admission (42.9\%), CSF leucocytic count $>1000 / \mathrm{mm} 3(21 \%)$. Of 75 adults who were treated for bacterial meningitis, 10 developed neurological complications (13.3\%) and seven patients died $(9.3 \%)$. The most important predictors for neurological complications in adults with bacterial meningitis were seizures on admission (20\%), the presence of co-morbidities (22.2\%), CSF leucocytic count $<1000 / \mathrm{mm} 3(14.7 \%)$. The seizures on admission, the presence of co-morbidities, CSF leucocytic count $<1000 / \mathrm{mm} 3$ proved to be the strongest predictors for neurological complications of bacterial meningitis in adult patients, on the other hand, age $<1$ year, seizures at admission ,CSF leucocytic count $>1000 / \mathrm{mm} 3$ proved to be the strongest predictors for neurological complica-tions of bacterial meningitis in children and valuable to select patients for more intensive therapy.

Key words: Neurological complications, acute bacterial meningitis, CSF leucocytic count.

\section{Introduction}

The meningitis is an inflammation of the membranes (leptomeninges) surrounding the brain and spinal cord and the intervening cerebrospinal fluid (Chanteau et al, 2006).

Acute meningitis is caused by a variety of infectious agents. The most serious form is caused by pyogenic bacteria, such as $S$. pneumoniae, $N$. meningitidis and $H$. influenzae (Tunkel and Scheld, 2005). Acute bacterial meningitis is a major cause of death and disability worldwide. It affects over one million people each year, and it is much more common in developing countries and in specific geographic areas such as the meningitis belt of Africa (Pfister and Roos, 2003).

It is an endemic disease in Egypt with $S$. pneumoniae is leading cause of the bacterial meningitis (42\%), followed by $H$. influenzae (20\%), N. meningitidis (16\%) and M. tuber- culosis (16\%) (Afifi et al, 2007). The typical CSF in patients with bacterial meningitis are neutrophil pleocytosis, decreased glucose concentration and increased protein concentration (Baud et al, 2018). Diagnosis is established by identification of the bacterial pathogen by microscopy of a Gram stained smear and by a positive CSF culture (Bannister et al, 2006) Gram stain is positive in identifying the meningeal pathogen in 36$90 \%$ (Brouwer et al, 2010). A wide range of CSF culture posit-ive ranged from $8-62 \%$ (Afifi et al, 2007). Bacterial culture takes at least 36 hours to obtain, and adversely affected by preadmission treatment with antibiotics. Several rapid diagnostic tests have been developed. Latex agglutination test detected bacterial antigens in $64 \%$ of cases (Narkeviciute et al, 2006). A broad range bacterial PCR assay is available for the early 
detection of bacterial meningitis with sensitivity (100\%) and specificity (98.2\%), also, the detect DNA of all meningeal pathogens (Saravolatz et al, 2003).

Meningitis can lead to serious long-term consequences as deafness, epilepsy, hydrocephalus and cognitive deficits, mainly if not treated quickly (Sáez-Llorens and McCracken, 2003; van de Beek et al, 2006). Although the occurrence of negative consequences of bacterial meningitis in developed countries is strongly reduced by the vaccination strategies, antibiotic treatment and good care facilities, bacterial meningitis is still responsible for substantial morbidity and mortality in both developed and developing countries (Theodoridou et al, 2007). The mortality rate was about 5\%, and long-term morbidity, mainly consisting of persistent neurological sequelae was 15\% (Pelkonen et al, 2009).

This study was a prospective study designed to analyze the data from 155 Egyptian patients who were admitted to hospital with suspected acute bacterial meningitis.

\section{Patients and Methods}

This study was conducted at Shebin ElKom Fever Hospital, Ministry of Health and Population. It included 80 children less than 16 years $(51.6 \%)$ and 75 adults more than 16 years $(48.4 \%)$. According to patient's age, the included patients were divided into two main groups: G1: patients with acute bacterial meningitis aged less than 16 years, and G2: patients with acute bacterial meningitis older than 16 years.

All patients were subjected to the following: Thorough history taking, full clinical examination, laboratory tests, and Lumbar puncture. In order to determine their association with the incidence of neurological complications of bacterial meningitis, nine potentially relevant predictors were chosen to be analyzed. These predictors included the following: Age, Gender, Duration of patient illness before admission, Previous treatment with antibiotics, Presence of disturbed consciousness level (DCL), Occurrence of seizures on admission, Initial single or dual an- tibiotic therapy, Presence or absence of comorbidities, CSF parameters (cell count, protein, glucose, culture). All patients fulfilled the following criteria: Patients admitted to hospital with suspected acute bacterial meningitis with clinical, laboratory \& CSF analysis diagnosed.

The patients were subjected to thorough history taking and clinical examination. They were examined by neurologist, ophthalmologist, ENT specialist and psychiatrists. The diagnosis of neurological complications was made by: Neurological examination, neuro-imaging (CT, \& MRI) of head. The following laboratory tests were done $\mathrm{CBC}$, CRP, ESR, Blood culture. Indications for performing a computed tomography (CT \& MRI) of head after meningitis were prolonged fever, focal neurological deficit, convulsion, worsening consciousness level, prolonged CSF cytochemical changes, worsening of clinical presentation. All patients were subjected to lumbar puncture. CSF analysis included: Cell count with differential, Glucose level, Protein level, Bacterial culture

Statistical analysis: Data were tabulated \& analyzed by SPSS statistical package version 20 on IBM compatible computer. Chi square test was done for qualitative variable analysis and P-value $<0.05$ was significant. Student t- test was done for normally distributed quantitative variables to measure mean and standard deviation and $\mathrm{P}$-value $<0.05$ was significant.

\section{Results}

The present study included one fifty five (155) patients with acute bacterial meningitis and classified into two groups according to their ages: G1: comprised 75 adults with acute bacterial meningitis. They were 61 males $(81.3 \%)$ and 14 females $(18.7 \%)$, with age more than 16 years $(36.0 \pm 15.0)$. G2: comprised 80 children with acute bacterial meningitis. They were 54 males $(67.5 \%)$ \& 26 females $(32.5 \%)$ with less than 16 years (4.5 \pm 3.7$)$.

There was a significant difference between both groups regarding DCL \& Brudzinski 
sign with $\mathrm{P}$-value $<0.05$. As to the headache, neck rigidity \& kernig sign there is a highly significant statistically difference between the two groups with P-value $<0.01$. Also, there was a statistically significant difference between the two groups when compared WBC count with p-value $<0.05$. As to PMN, blood glucose \& ESR there was a high significant difference between the two groups with higher value in adult $(\mathrm{P}$-value < $0.01)$.

There was no significant difference between en groups as to CSF (protein \& glucose) with (P> 0.05), but CSF (leucocytes, PMN $\&$ lymphocyte) gave a highly significant difference between groups with $\mathrm{P}<0.01$ (Tab. $1)$.

Regarding outcome there was a highly statistically significant difference between the two groups with $\mathrm{P}<0.01$ (Tab. 2). During the fourteen months study period, 155 patients were treated for acute bacterial meningitis (80 Children \& 75 adults). Of children treated as bacterial meningitis, 8 (10\%) developed neurological complications as quadriparesis $1 / 80(1.25 \%)$, hemiparesis $3 / 80(3.75 \%)$, subdural effusion $1 / 80$ $(1.25 \%)$, squint $2 / 80(2.50 \%)$ hearing loss $1 / 80(1.25 \%)$, hydrocephalus $2 / 80$ (2.5\%). Of adults treated as acute bacterial meningitis, $10(13.3 \%)$ developed neurological complication as squint and speech disorder, hemiparesis, vision loss, quadri-paresis, aphasia and hemiparesis, brain stem herniation, cerebritis with small abscess formation, amnesia \& insomnia, cerebral edema and headache with dizziness, each was $1 / 75(1.33 \%)$.

Neurological complications in both groups were, 3 patients complicated by squint
( 2 children \& 1 adult), 4 patients complicated by hemi paresis ( 3 children $\& 1$ adult), 2 children complicated by hydrocephalus, 2 patients complicated by quadriparesis (1 child \& 1 adult), one patient for each remained complications. Highest neurological complications were in children less than one year $(6.3 \%)$ with significant association $(\mathrm{P}<$ 0.05) (Tabs. 3, 4).

There was significant association between seizures at admission, comorbidity and neurological complications development $(\mathrm{P}<$ $0.05)$. Highest incidence of neurological complications was in children $(33.3 \%)$ more than adults (25\%) with DCL, but without significant. Highest neurological complication was in children $(42.9 \%)$ than in adult (20\%) with seizures at the admission with significant association (Tab.5).

In the present study, there was high significant association between CSF leucocytes $>1000$ and development of the neurological complications $(\mathrm{P}<0.01)$ with higher value in children $(21.1 \%)$ more than in adults $(12.2 \%)$ with acute bacterial meningitis. CSF leucocytes $<1000$ associated with neurological complication development in the adults $(14.7 \%)$ more than children $(6.6 \%)$ with $\mathrm{ABM}(\mathrm{P}<0.01)$. Highest incidence of neurological complication in children (17.6) was more than adults (7.7\%) with CSF glucose $<45$, but without significant. Highest incidence of neurological complications in adults (13.7) was more than children (9.9\%) with CSF protein > 50, without significant. Highest neurological complication incidence was in adults (19\%) more than children (14.8\%) with CSF PMN >50\%, without significant (Tab. 6).

Table 1: Comparison between both groups regarding CSF parameters

\begin{tabular}{|c|c|c|c|c|c|c|c|}
\hline \multicolumn{2}{|l|}{ CSF parameter } & \multicolumn{2}{|c|}{ Adults $(\mathrm{N}=75)$} & \multicolumn{2}{|c|}{ Children $(\mathrm{N}=80)$} & T. test & $\mathrm{P}$ value \\
\hline \multicolumn{2}{|l|}{ leucocyte } & \multicolumn{2}{|c|}{$2929.1 \pm 6391.2$} & \multicolumn{2}{|c|}{$896.9 \pm 1222.3$} & $2.8^{* *}$ & $<0.01$ \\
\hline \multicolumn{2}{|l|}{ PMN\% } & \multicolumn{2}{|c|}{$52.7 \pm 30.0$} & \multicolumn{2}{|c|}{$38.3 \pm 27.3$} & $3.1 * *$ & $<0.01$ \\
\hline \multicolumn{2}{|l|}{ Lymph\% } & \multicolumn{2}{|c|}{$45.1 \pm 29.4$} & \multicolumn{2}{|c|}{$61.7 \pm 27.3$} & $-3.6 * *$ & $<0.01$ \\
\hline \multicolumn{2}{|l|}{ protein } & \multicolumn{2}{|c|}{$159.5 \pm 155.5$} & \multicolumn{2}{|c|}{$124.8 \pm 144.0$} & 1.4 & $>0.05$ \\
\hline \multicolumn{2}{|l|}{ glucose } & \multicolumn{2}{|c|}{$55.9 \pm 26.7$} & \multicolumn{2}{|c|}{$58.1 \pm 21.1$} & -0.6 & $>0.05$ \\
\hline \multirow{2}{*}{ CSF Culture } & -ve & 66 & $88.0 \%$ & 71 & $88.8 \%$ & $\mathrm{X}^{2}$ & \multirow{2}{*}{$>0.05$} \\
\hline & $+\mathrm{ve}$ & 9 & $12.0 \%$ & 9 & $11.3 \%$ & 0.02 & \\
\hline
\end{tabular}

CSF: cerebrospinal fluid, PMN: polymorph nuclear leucocytes. 
Table 2: Comparison between both groups as to ICU admission, outcome \& neurological complications.

\begin{tabular}{|c|c|c|c|c|c|c|c|}
\hline \multicolumn{2}{|l|}{ Parameters } & \multicolumn{2}{|c|}{ Adults $(\mathrm{N}=75)$} & \multicolumn{2}{|c|}{ Children $(\mathrm{N}=80)$} & \multirow{2}{*}{$X^{2}$} & \multirow{2}{*}{$P$ value } \\
\hline & & No & $\%$ & No & $\%$ & & \\
\hline \multirow{2}{*}{ ICU admission } & No & 64 & 85.3 & 72 & 90.0 & \multirow[t]{2}{*}{0.784} & \multirow[t]{2}{*}{$>0.05$} \\
\hline & Yes & 11 & 14.7 & 8 & 10.0 & & \\
\hline \multirow[t]{3}{*}{ Outcome } & cured & 63 & 84.0 & 78 & 97.5 & \multirow{3}{*}{$9.73 * *$} & \multirow{3}{*}{$<0.01$} \\
\hline & Referred & 5 & 6.7 & 2 & 2.5 & & \\
\hline & death & 7 & 9.3 & 0 & 0 & & \\
\hline \multirow{2}{*}{$\begin{array}{l}\text { Neurological com- } \\
\text { plications }\end{array}$} & No & 65 & 86.7 & 72 & 90.0 & \multirow[t]{2}{*}{0.42} & \multirow[t]{2}{*}{$>0.05$} \\
\hline & Yes & 10 & 13.3 & 8 & 10.0 & & \\
\hline
\end{tabular}

ICU: intensive care unite

Table 3: Neurological complications in both groups

\begin{tabular}{|c|c|c|c|c|}
\hline \multirow[t]{2}{*}{ Complications } & \multicolumn{2}{|c|}{ Adults $(\mathrm{N}=75)$} & \multicolumn{2}{|c|}{ Children $(\mathrm{N}=80)$} \\
\hline & No & $\%$ & No & $\%$ \\
\hline Squint \& speech disorder & 1 & 1.33 & 0 & 0 \\
\hline Paraparesis & 1 & 1.33 & 0 & 0 \\
\hline Loss of vision & 1 & 1.33 & 0 & 0 \\
\hline Quadriparesis & 1 & 1.33 & 1 & 1.25 \\
\hline Aphasia \& hemiparesis & 1 & 1.33 & 0 & 0 \\
\hline Brain stem herniation & 1 & 1.33 & 0 & 0 \\
\hline Cerebritis \&small abscess formation & 1 & 1.33 & 0 & 0 \\
\hline Amnesia \& insomnia & 1 & 1.33 & 0 & 0 \\
\hline Hemiparesis \&squint & 0 & 0 & 1 & 1.25 \\
\hline Hearing loss-Hemiparesis & 0 & 0 & 1 & 1.25 \\
\hline Subdural effusion & 0 & 0 & 1 & 1.25 \\
\hline Hydrocephalus & 0 & 0 & 2 & 2.5 \\
\hline Hemiparesis & 0 & 0 & 1 & 1.25 \\
\hline Squint & 0 & 0 & 1 & 1.25 \\
\hline Cerebral edema & 1 & 1.33 & 0 & 0 \\
\hline Headache and dizziness & 1 & 1.33 & 0 & 0 \\
\hline Total & 10 & 13.3 & 8 & 10 \\
\hline
\end{tabular}

Table 4: Association between age grouping and development of neurological complications

\begin{tabular}{|c|c|c|c|c|}
\hline \multicolumn{2}{|l|}{ Age } & No complications & $\%$ & $\mathrm{P}$ value \\
\hline \multirow[t]{3}{*}{ adults } & $16-30$ & 3 & 4 & \multirow{3}{*}{$>0.05$} \\
\hline & $30-50$ & 4 & 5.3 & \\
\hline & $>50$ & 3 & 4 & \\
\hline \multirow[t]{3}{*}{ children } & $<1$ year & 5 & 6.3 & \multirow{3}{*}{$<0.05$} \\
\hline & 1 to 2 year & 0 & 0 & \\
\hline & $>2$ year & 3 & 3.75 & \\
\hline \multicolumn{2}{|l|}{ P.value } & \multicolumn{2}{|l|}{$>0.05$} & \\
\hline
\end{tabular}

Table 5: Association between DCL, seizures, DM, HTN, blood neutrophil \% \& development of neurological complications

\begin{tabular}{|c|c|c|c|c|c|c|c|c|}
\hline \multirow{2}{*}{\multicolumn{2}{|c|}{ Parameters }} & \multirow{3}{*}{$\begin{array}{l}\text { Complications } \\
\text { No } \\
\end{array}$} & \multicolumn{2}{|c|}{ Adults $(\mathrm{N}=75)$} & \multicolumn{2}{|c|}{ Children $(\mathrm{N}=80)$} & \multirow{2}{*}{$\mathrm{X} 2$} & \multirow{2}{*}{ P.value } \\
\hline & & & No & $\%$ & No & $\%$ & & \\
\hline \multirow{4}{*}{ DCL } & \multirow{2}{*}{$+\mathrm{ve}$} & & 18 & 75.0 & 10 & 66.7 & \multirow{2}{*}{0.53} & \multirow{2}{*}{$>0.05$} \\
\hline & & Yes & 6 & 25.0 & 5 & 33.3 & & \\
\hline & \multirow{2}{*}{-ve } & No & 47 & 92.2 & 62 & 95.4 & \multirow{2}{*}{0.32} & \multirow{2}{*}{$>0.05$} \\
\hline & & Yes & 4 & 7.8 & 3 & 4.6 & & \\
\hline \multirow{4}{*}{ Seizures } & \multirow{2}{*}{$+\mathrm{ve}$} & No & 8 & 80.0 & 8 & 57.1 & \multirow{2}{*}{$3.99 *$} & \multirow{2}{*}{$<0.05$} \\
\hline & & Yes & 2 & 20.0 & 6 & 42.9 & & \\
\hline & \multirow[b]{2}{*}{-ve } & No & 57 & 87.7 & 64 & 97.0 & \multirow{2}{*}{2.61} & \multirow{2}{*}{$>0.05$} \\
\hline & & Yes & 8 & 12.3 & 2 & 3.0 & & \\
\hline \multirow{4}{*}{ DM } & \multirow[b]{2}{*}{$+\mathrm{ve}$} & No & 7 & 77.8 & 0 & 0 & \multirow{2}{*}{$8.1^{*}$} & \multirow{2}{*}{$<0.05$} \\
\hline & & Yes & 2 & 22.2 & 0 & 0 & & \\
\hline & \multirow{2}{*}{-ve } & No & 58 & 87.9 & 72 & 90.0 & \multirow{2}{*}{1.8} & \multirow{2}{*}{$>0.05$} \\
\hline & & Yes & 8 & 12.1 & 8 & 10.0 & & \\
\hline \multirow{4}{*}{ HTN } & \multirow[b]{2}{*}{$+\mathrm{ve}$} & No & 5 & 71.4 & 0 & 0 & \multirow{2}{*}{$5.75^{*}$} & \multirow{2}{*}{$<0.05$} \\
\hline & & Yes & 2 & 28.6 & 0 & 0 & & \\
\hline & \multirow{2}{*}{-ve } & No & 60 & 88.2 & 72 & 90.0 & \multirow{2}{*}{1.8} & \multirow{2}{*}{$>0.05$} \\
\hline & & Yes & 8 & 11.8 & 8 & 10.0 & & \\
\hline & & No & 63 & 86.3 & 34 & 87.2 & & \\
\hline PMN & $>60 \%$ & Yes & 10 & 13.7 & 5 & 12.8 & 0.316 & $>0.05$ \\
\hline & $<60 \%$ & No & 2 & 100 & 38 & 92.7 & 0.673 & $>0.05$ \\
\hline
\end{tabular}

DCL: disturbed conscious level 
Table 6: Association between CSF parameters and the development of neurological complications.

\begin{tabular}{|c|c|c|c|c|c|c|c|c|}
\hline \multirow{2}{*}{\multicolumn{2}{|c|}{ CSF parameters }} & \multirow{3}{*}{$\begin{array}{l}\text { Complications } \\
\text { No }\end{array}$} & \multicolumn{2}{|c|}{ Adults $(\mathrm{N}=75)$} & \multicolumn{2}{|c|}{ Children $(\mathrm{N}=80)$} & \multirow{2}{*}{$\mathrm{X} 2$} & \multirow{2}{*}{ P.value } \\
\hline & & & No & $\%$ & No & $\%$ & & \\
\hline \multirow{4}{*}{ Glucose } & \multirow{2}{*}{$>45$} & & 41 & 83.7 & 58 & 92.1 & \multirow{2}{*}{1.89} & \multirow{2}{*}{$>0.05$} \\
\hline & & Yes & 8 & 16.3 & 5 & 7.9 & & \\
\hline & \multirow{2}{*}{$<45$} & No & 24 & 92.3 & 14 & 82.4 & \multirow{2}{*}{0.99} & \multirow{2}{*}{$>0.05$} \\
\hline & & Yes & 2 & 7.7 & 3 & 17.6 & & \\
\hline \multirow{4}{*}{ Protein } & \multirow{2}{*}{$>50$} & No & 63 & 86.3 & 64 & 90.1 & \multirow{2}{*}{0.316} & \multirow{2}{*}{$>0.05$} \\
\hline & & Yes & 10 & 13.7 & 7 & 9.9 & & \\
\hline & \multirow{2}{*}{$<50$} & No & 2 & 100.0 & 8 & 88.9 & \multirow{2}{*}{0.14} & \multirow{2}{*}{$>0.05$} \\
\hline & & Yes & 0 & 0.0 & 1 & 11.1 & & \\
\hline \multirow{4}{*}{$\begin{array}{l}\text { Leuco- } \\
\text { cytes }\end{array}$} & \multirow{2}{*}{$\begin{array}{l}>100 \\
0\end{array}$} & No & 36 & 87.8 & 15 & 78.9 & \multirow{2}{*}{17.45} & \multirow{2}{*}{$<0.01$} \\
\hline & & Yes & 5 & 12.2 & 4 & 21.1 & & \\
\hline & \multirow{2}{*}{$\begin{array}{l}<100 \\
0\end{array}$} & No & 29 & 85.3 & 57 & 93.4 & \multirow{2}{*}{13.4} & \multirow{2}{*}{$<0.01$} \\
\hline & & Yes & 5 & 14.7 & 4 & 6.6 & & \\
\hline \multirow{4}{*}{ PMN } & \multirow{2}{*}{$>50$} & No & 34 & 81.0 & 23 & 85.2 & \multirow{2}{*}{2.697} & \multirow{2}{*}{$>0.05$} \\
\hline & & Yes & 8 & 19.0 & 4 & 14.8 & & \\
\hline & \multirow{2}{*}{$<50$} & No & 31 & 93.9 & 49 & 96.1 & \multirow{2}{*}{1.05} & \multirow{2}{*}{$>0.05$} \\
\hline & & Yes & 2 & 6.1 & 4 & 7.8 & & \\
\hline & & No & 58 & 87.9 & 65 & 91.5 & 004 & \\
\hline Culture & -ve & Yes & 8 & 12.1 & 6 & 8.5 & 0.04 & $>0.05$ \\
\hline & & No & 7 & 77.8 & 7 & 77.8 & & \\
\hline & $+\mathrm{ve}$ & Yes & 2 & 22.2 & 2 & 22.2 & 0.06 & $>0.05$ \\
\hline
\end{tabular}

Discussion

Generally speaking, the meningitis is typically caused by an infection with microorganisms as viral (Logan and MacMahon, 2008), bacteria, fungal (Bicanic and Harrison, 2004), parasitic (El Bahnasawy et al, 2016) and non-infectious caused spread of cancer to meninges (Gleissner and Chamberlain, 2006), certain drugs (Moris and Garcia-Monco, 1999), certain forms of vasculitis as Behçet's disease (Ginsberg, 2004) and other factors

In the present study, all patients were presented with fever $(100 \%)$, headache $(94 \%)$, and Neck rigidity (88\%). Only $32 \%$ showed DCL, 57\% had Kernig sign, which was higher than the rate in others. Bodin et al. (2004) reported that only $54 \%$ had the classic clinical trial (headache, neck rigidity and DCL). Durand et al. (1993) and Sigurdardottir et al. (1997) reported that the classic symptoms ranged from $33-66 \%$. In the present study, seizure was reported in (12-17\%), which was higher than the rate reported in other $(8.9 \%)$ (Bodin et al, 2004) and lower than rates in other studies, $(23 \%)$ in (Durand et al, 1993; Sigurdardottir et al, 1997). This study showed a highly significant dif- ference in comorbidity $(\mathrm{P}<0.01)$, which was common in adults The result agreed with Rabbani et al. (2003) who stated that more than $70 \%$ of the patients had at least one underlying disease or condition

There was no statistically significant difference in pre-antibiotics use $(\mathrm{P}>0.05)$ between the two studied groups. This result agreed with Namani et al. (2013) who found that patients $(49 \%)$ were previously treated with antibiotics but without associated with increased incidence of neurological complications. But, Namani et al. (2012) found that previous treatment with antibiotics was associated with increased risk for death.

In the present study, there were a highly significant difference in CRP with P-value $<0.01$ between both groups with acute bacterial meningitis that was higher value in adults. These results agreed with Sormunen et al. (1999) who reported that only CRP identified gram stain negative bacterial meningitis from viral meningitis on admission with the high sensitivity (96\%), high specificity $(93 \%)$ and high negative predictive value (99\%). In the present study, there was high significant difference in the CSF WBC, CSF polymorphs and the CSF lymphocyte\% 
between both groups $(\mathrm{P}<0.01)$ with high value in adults as to CSF WBC and CSF polymorphs with higher in children as to CSF lymphocyte\% but without significant difference as to CSF glucose and protein between both groups. Namani et al. (2013) reported low CSF leukocyte count, low CSF glucose level, low CSF/ blood glucose level, and high CSF protein level were identified as significant factor predicting to neurological bacterial meningitis complications.

In the present study, hearing $(1.25 \%)$ was lower than reported worldwide. It varied between 5.6-23\% (Singhi et al, 2007). The hearing loss after bacterial meningitis may be transient or permanent. Transient hearing loss may be secondary to a conductive disturbance in many affected patients. But, sensorineural hearing loss (transient or permanent) resulted from damage of the $8^{\text {th }}$ cranial nerve, cochlea, or labyrinth, induced by direct bacterial invasion and/or inflammatory response elicited by infection (Koomen et al, 2003).

The present study showed highest incidence of neurological complications in children less than a year $(6.3 \%)$ with significant difference. Namani et al. (2013) found that age $<12$ months was proved predictor for neurological complications and age $<12$ months was a risk factor for early neurological complication and long term sequelae in children. Antoniuk et al. (2011) reported that childhood acute bacterial meningitis was associated with a high risk of complications and neurological sequelae with $40 \%$, the warning signs for acute neurological complications were seizure episodes at admission, neutropenia $<60 \%$ and low ages. The present study showed a significant association between seizures at admission, comorbidity and neurological complications development $(\mathrm{P}$ $<0.05)$.

Incidence of neurological complications of acute bacterial meningitis was in children $(42.9 \%)$ more than adults $(20 \%)$ with seizures at admission. Patients presented with
DCL at admission were liable to neurological complications; $33.3 \%$ in children \& $25 \%$ in adults. Antoniuk et al. (2011) found that the presence of seizure episodes as an important factor of poor prognosis, neurological sequelae was detected in $36 \%$ of patients with epileptic manifestation. Hsu et al. (2018) reported that patients presented with early seizure or septic shock were an early predictor of final outcomes and require close monitoring.

In the present, the higher incidence of neurological complications was in patients with CSF protein $>50 \mathrm{mg}$ ( $13.7 \%$ in adults $\& 9.9 \%$ in children), without significant ( $\mathrm{P}$ $>0.05)$. This agreed with Namani et al. (2013) who reported only increased CSF protein level as risk factor for neurological complications. Koomen et al. (2003) reported that low CSF leukocyte, low CSF glucose level and high CSF protein level were significant factors predicting neurological complications in children in both the developed and developing countries.

In the present study, the higher neurological complications incidence was in children with CSF/glucose $<45 \mathrm{mg}(17.6 \%)$ more than adults $(7.7 \%)$, without significant ( $\mathrm{p}>0.05)$. Namani et al. (2011) reported that alteration in various CSF parameters associated with development of ne-urological complications as low CSF leucocytic count, decreased glucose level in CSF \& elevated CSF protein level. Tasai et al. (2008) reported that CSF leucocytic count $<200 \mathrm{~mm} \&$ protein level $>330 \mathrm{gm}$ were significant risk factors associated with poor outcome and added that physician must be cautious with such conditions.

\section{Conclusion}

Generally, meningitis is an acute inflammation of protective membranes covering the brain and spinal cord, known collectively as the meninges.

The empiric antibiotics (treatment without the exact diagnosis) must start immediately, even before the results of the lumbar puncture and CSF analysis are available. 
The choice of the initial treatment depends largely on the bacteria kind that cause meningitis in a particular place and population, keeping in mind that meningitis can be diagnosed after death.

Since, penicillin has remained the drug of choice for the meningococcal meningitis treatment. However, current the IDSA guidelines list Ceftriaxone ${ }^{\circledR}$ or Cefotaxime ${ }^{\circledR}$ as the best drugs of choice.

\section{References}

Afifi, S, Wasfy, MO, Azab, MA, Youssef, F G, Pimentel, G, et al, 2007: Laboratory-based surveillance of patients with bacterial meningitis in Egypt (1998-2004). Eur. J. Clin. Microbiol. Infect. Dis. 26, 5:331-40.

Antoniuk, S, Hamdar, F, Renata, D, Kira, A, Mônica N, et al, 2011: Childhood acute bacterial meningitis: risk factors for acute neurological complications and neurological sequelae. J. Pediatr. (Rio J). 87, 6:535-40.

Bannister, BA, Gillespie, SH, Jones, J. 2006: Infections of central nervous system. In: Infection: Microbiology and Management. $3^{\text {rd }}$ edition. Blackwell.

Baud, MO, Vitt, JR, Nathaniel M. Robbins, NM, Wabl, R, Michael R. Wilson, MR, et al, 2018: Pleocytosis is not fully responsible for low CSF glucose in meningitis. Neurol. Neuroimmunol. Neuroinflamm. 5, 1: e425.

Bicanic, T, Harrison, TS, 2004: Cryptococcal meningitis. Br. Med. Bull. 72, 1:99-118.

Bodin, K, Pantip, C, Alan, G, 2004: Acute bacterial meningitis in adults: A 20 year review. Southeast Asian J. Trop. Med. Publ. Hlth. 35, 4: 886-92.

Brouwer MC, Tunkel AR, van de Beek D. 2010: Epidemiology, diagnosis, and antimicrobial treatment of acute bacterial meningitis. Clin. Microbiol. Rev. 23:467-92

Chanteau S, Dartevelle S, Mahamane AE, Djibo S, Boisier P, et al, 2006: New rapid diagnostic tests for Neisseria meningitidis sero-groups A, W135, C, \& Y. PLoS Med. 3:33-7.

Durand ML, Calderwood SB, Weber DJ, Miller SI, Southwick FS, et al, 1993: Acute bacterial meningitis in adults: A review of 493 episodes. N. Engl. J. Med. 328:21-8.

El-Bahnasawy, MMN, El Feky, MR, Morsy, ATA, Ismail, MA, Morsy, TA, 2016: Egyptian eosinophilic and infectious meningoencephalitis and their impact on psychological aspects. J. Egypt. Soc. Parasitol. 46, 1:67-80.

Ginsberg, L, 2004: Difficult and recurrent meningitis. J. Neurol. Neurosurg. Psychiat. 75, 1 (90001):i1621.

Gleissner, B, Chamberlain, MC, 2006: Neoplastic meningitis. Lancet Neurol. 5, 5:443-52.

Hsu MH, Hsu JF, Kuo HC, Lai, MY, Chiang MC, et al, 2018: Neurological complications in young infants with acute bacterial meningitis. Front Neurol. 24, 9:903-6

Koomen, I, Grobbee, DE, Roord, JJ, Donders, R, Jennekens, A, et al, 2003: Hearing loss at school age in survivors of bacterial meningitis: assessment, incidence and prediction. Pediatr. 112, 5:1049-53.

Logan, SA, MacMahon, E, 2008: Viral meningitis. BMJ 336, 7634:36-40.

Moris, G, Garcia-Monco, JC, 1999: The challenge of drug-induced aseptic meningitis. Arch. Inter. Med. 159, 11:1185-94.

Namani S, Milenkovi Z, Buleza K, et al, 2013: A prospective study of risk factors for neurological complications in childhood bacterial meningitis. J. Pediatr. (Rio J). 89, 3:256-62

Namani, S, Koci, BM, Milenkovi, Z, et al, 2012: Early neurologic complications and longterm sequelae of childhood bacterial meningitis in a limited-resource country (Kosovo). J. Child Neurol. 27:46-50.

Namani, S, Remzie, R, Dedushi, K, 2011: Predictors for Neurologic complications of bacterial meningitis in children in Kosovo Macedonian. J. Med. Sci.15, 41:75-80

Narkeviciute I, Bernatoniene J, Mikelionyte A, et al, 2006: Etiological diagnostics of acute bacterial meningitis in children. Scand. J. Infect. Dis. 38:782-7.

Pelkonen T, Roine I, Monteiro L, Correia M, Pitkäranta A, et al, 2009: Risk factors for death and severe neurological sequelae in childhood bacterial meningitis in sub-Saharan Africa. Clin. Infect. Dis. 48:1107-10.

Pfister, W, Roos, KL, 2003: Bacterial meningitis. In: Principles of Neurologic Infectious Diseases. Roos KL (ed.), McGraw-Hill.

Rabbinic, M, Khan, S, Ali, B, Ahmad, B, Ba ig, SM, et al, 2003: Spectrum of complications and mortality of bacterial meningitis: An experience from a developing country. JPMA 53:580-4 Sáez-Llorens, X, McCracken, GH, 2003: Bacterial meningitis in children. Lancet 361, 9375: 2139-48 
Saravolatz, LD, Manzor, O, VanderVelde, N, Pawlak, J, Belian, B, 2003: Broad-range bacterial polymerase chain reaction for early detection of bacterial meningitis. Clin. Infect. Dis. 36:40-5.

Sigurdardottir, B, Bjornsson, OM, Jonsdit-tr, KE, Erlendsdóttir, H, Gudmundsson, S, 1997: Acute bacterial meningitis in adults: A 20 year review. Arch. Inter. Med. 157:425-30

Singhi, P, Arun, B, Geeta, P, Singhi, S, 2007: Predictors of long term neurological outcome in bacterial meningitis. Indian J. Pediatr. 74, 4:36974

Sormunen, P, Kallio, MJ, Kilpi, T, Peltola, H, 1999: C-reactive protein is useful in distinguishing gram stain-negative bacterial meningitis from viral meningitis in children. J. Pediatr.134, 6:725-9.
Tasai, MH, Chen, SH, Hsu, CY, 2008: Pneumococcal meningitis in Taiwanese Children: Emphasis on clinical outcomes and prognostic factors. J. Trop. Pediatr. 54:34547

Theodoridou, MN, Vasilopoulou, VA, Atsali, EE, Pangalis, AM, Mostrou, GJ, et al, 2007: Meningitis registry of hospitalized cases in children: epidemiological patterns of acute bacterial meningitis throughout a 32-year period. BMC Infect. Dis. 7:101-6. Tunkel, AR, Scheld, WM, 2005: Acute men

ingitis. In: Principles and Practice of Infectious Disease. By Mandell, GL, Bennett, JE, Dolin, R. (ed.) $6^{\text {th }}$ ed. Elsevier, Churchill Livingstone.

Van de Beek, D, de Gans, J, Tunkel, AR, Wijdicks, EF, 2006: Community-acquired bacterial meningitis in adults. N. Engl. J. Med. 354:44-53. 